378.147::811.163.41'243(495)

https://doi.org/10.18485/msc_saopstenja.2018.48.1.ch21

Војкан Б. СТОЈИЧИЋ* Универзитет у Београду Филолошки факултет
Прегледни рад

Примљен: 24. 09. 2018. Прихваћен: 03. 12. 2018.

\title{
СРПСКИ ЈЕЗИК КАО СТРАНИ У РЕПУБЛИЦИ ГРЧКОЈ - ИЗАЗОВИ И ПЕРСПЕКТИВЕ $* *$
}

\begin{abstract}
Овај рад се бави анализом актуелног положаја српског језика као страног у Републици Грчкој како на универзитетима, тако и у другим институцијама од друштвеног и културног значаја. Имајући у виду бројне препоруке Савета Европе у којима се истиче важност учења страних језика, као део политике о мултијезичности и мултикултуралности, у раду ће бити представљени резултати анкете спроведене међу студентима Аристотеловог универзитета у Солуну, који дужи низ година (током јула месеца) похађају наставу српског језика као страног на Филолошком факултету у Београду. Анализирани анкетни листићи недвосмислено указују на чињеницу да је неопходна свестранија научна, просветна и културна сарадња између грчког и српског народа. Најзад, тренутна међууниверзитетска сарадња подстиче стварање многих екстралингвистичких фактора који обезбеђују бољу перспективу учења нашег језика, што се посебно види из анализираних упитника.
\end{abstract}

Кључне речи: српски језик као страни, настава, Република Грчка, мотивација, учење.

\section{1. Настава српског језика као страног у Грчкој ${ }^{1}$}

Настава српског језика као страног одвија се данас на два универзитета у Републици Грчкој - на Универзитету Македонија² у Солуну, при Катедри за балканске, словенске и источне студије ${ }^{3}$, као и на Националном и каподистријском универзитету у Атини ${ }^{4}$, при Катедри за руски језик, филологију

*vojkans@hotmail.com

** Рад је написан у оквиру пројекта Министарства просвете, науке и технолошког развоја Републике Србије Језиии и културе у времену и простору, број 178002.

${ }^{1}$ Велику захвалност аутор рада дугује мр Марици Јелић Кубуриду и др Биљани Турањанин Николопулос на пруженим релевантним подацима у вези са наставом српског језика на Универзитету Македонија у Солуну, одн. на Атинском универзитету.

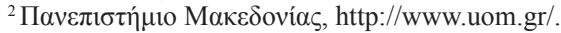

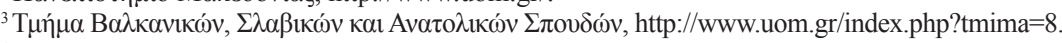

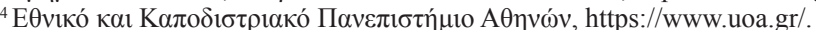


и словенске студије ${ }^{5}$, одн. при Центру за стране језике ${ }^{6}$. Поред ова два универзитетска центра, наставу српског језика као страног могуће је похађати данас и на Институту за балканолошке студије у Солуну ${ }^{7}$, као и у приватним центрима за учење страних језика у Атини и Солуну. Најзад, српски језик се изучавао пуних четрнаест година и на Универзитету Западне Македоније у Флорини ${ }^{8}$, при Катедри за балканске студије 9

\section{2. Универзитет Македонија у Солуну}

Настава српског језика као страног на Универзитету Македонија одвија се готово две деценије. Захваљујући напорима мр Марице Јелић Кубуриду од академске 2000/2001. године студенти Катедре за балканске, словенске и источне студије похађали су наставу српског језика као страног током треће и четврте године основних академских студија, закључно са 2013. годином. Руски и турски језик тада су били обавезни језици по избору, а српски, бугарски, арапски, румунски и пољски изборни страни језици. Укупан фонд часова српског језика био је 2+2 часа недељно. Године 2013 , одлуком ${ }^{10}$ Министарства просвете, вера, културе и спорта Републике Грчке, Катедра за балканске студије Универзитета Западне Македоније у Флорини припојена је Универзитету Македонија у Солуну, што је довело до промена у студијском програму и називу саме катедре. Новооснована, Катедра за балканске, словенске и источне студије реализује наставу из своје научне области кроз два студијска програма: 1) Програм балканских студија и 2) Програм словенских и источних студија. Од спајања двеју катедара, статус српског језика се мења набоље. Студентима је српски језик обавезни изборни језик ${ }^{11}$ у трајању од четири године са укупним недељним фондом од 2+2 часа предавања и вежби. Академске 2014/2015. и 2015/2016. године наставу је похађала једна група студената (20 полазника), док је током 2016/2017. и 2017/2018. године наставу српског језика пратило двоструко више студената (2 групе, 40 студената). Модел четворогодишњег програма српског језика као страног преузет је са Универзитета Западне Македоније, јер је спајањем двеју катедара повећан и број студената, али и број предавача који држе наставу српског језика.

Током прве три године предавачи у настави користе уџбенике Научимо српски 1 и 2 у издању Филозофског факултета Универзитета у Новом Саду,

${ }^{5}$ Т $\mu \eta ́ \mu \alpha$ Р

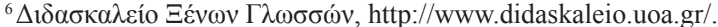

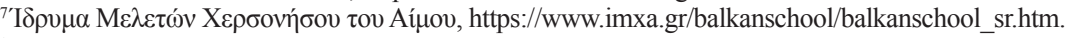

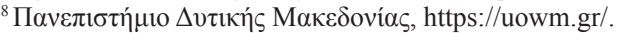

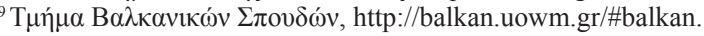

${ }^{10}$ На основу одлуке број 1236/6-02-2013, професори српског језика и српске књижевности са Универзитета Западне Македоније у Флорини од академске 2013/2014. године своје радне задатке обављају на Универзитету Македонија у Солуну. За више информација в. file://C:/Users/ USER/Downloads/sxedio-athina-new-pamak-5-martiou-2013.pdf.

${ }^{11}$ Студентима је обавезни страни језик руски или турски, док за други страни језик могу одабрати између српског, бугарског и румунског језика. 
уџбеничке комплете Српски језик за странще Института за стране језике у Београду, као и уџбенички комплет Учимо српски 1 у издању Азбукума. На четвртој години основних академских студија, у оквиру курева Српски језик 7 и 8 , студенти се упознају са стручном, економском и правном терминологијом, будући да већи део курсева које прате на факултету спада у област правно-економских наука. Такође, студенти могу пратити и курсеве српске књижевности, културе и цивилизације кроз посебне тематске блокове ${ }^{12}$. Пратећи савремене тенденције у настави страних језика, а на основу финансијских средстава које је обезбедила Европска унија у оквиру ЕСПА пројекта, припремљена је и дигитализована серија предавања (Српски језик 1, 2, 3 и 4), која је доступна на интернет презентацији Универзитета Македонија ${ }^{13}$. Ценећи, пре свега, жељу да се помогне студентима и другим заинтересованим лицима да науче српски језик, ипак морамо указати на постојање одређених недоследности, које је могуће пронаћи у презентацијама које прате ове курсеве на даљину. Све ово указује да је потреба за ангажовањем стручњака у домену србистике и више него потребна.

Најзад, повећање броја студената у протекле две академске године обрнуто је пропорционално новчаним средствима која се издвајају за ангажовање мр Јелић Кубуриду. Статус наших лектора није регулисан на Универзитету Македонија, као што није ни на Атинском универзитету, будући да предавачи нису у сталном радном односу. Управо овде Република Србија може помоћи правилним одабиром одговарајућих кандидата, који би у својству лектора радили на универзитетима у Грчкој. Посебна процедура за одабир лектора код нас још увек не постоји, а најчешће се бирају на основу протокола о билатералној сарадњи, на основу међууниверзитетских споразума или на индивидуалној основи. Као модел по коме би Република Србија могла решавати питање језичке и културне политике, могао би послужити управо грчки, уколико држава Србија препозна значај језичких амбасадора у свету.

Ако бисмо упоредили статус модерног грчког језика као страног у свету, са статусом српског као страног, ситуација је драстично различита. Надлежне институције Републике Грчке (као што су Министарство просвете и вера, Министарство иностраних послова, Центар за грчки језик, Центар за питање Грка у иностранству и друге) пружају перманентну подршку дисеминацији и промоцији модерног грчког језика. То управо значи да је питање ангажовања лектора у иностранству решено законодавним путем. Као лектори могу бити ангажовани већ запослени филолози (дипломци неохеленистике, класичних наука, филозофије, историје и археологије), који раде у средњошколском систему образовања у Републици Грчкој, односно професори разредне наставе (могу бити ангажовани углавном у раду са децом школског узраста, а по потреби и на универзитетима). Посебне координационе јединице налазе се широм света, а раде у оквиру дипломатско-конзуларних представништава Републике Грчке. Дакле, у Републици Грчкој постоје тачно утврђена правила

\footnotetext{
${ }^{12}$ Наставу из ових предмета изводи доц. др Ставрула Маврогени.

${ }^{13}$ Више информација можете пронаћи на http://opencourses.uom.gr/courses/balkanikesslabikes-anatolikes-spoudes.
} 
и конкурси за обављање ових послова који су за сваку државу од изузетног значаја (Стојичић, 2016).

\section{3. Национални и каподистријски универзитет у Атини}

Настава српског језика као страног на Филозофском факултету Националног и каподистријског универзитета у Атини реализује се од академске 2013/2014. године при Катедри за руски језик, филологију и словенске студије $^{14}$. Студенти руског језика и књижевности бирали су обавезни, други словенски језик (српски, бугарски, украјински или пољски) од друге године студија, а настава се одвијала током шест семестара (у другој, трећој и четвртој години основних академских студија). Студенти су били у обавези да прате наставу из другог словенског језика током два семестра, док је у преостала четири семестра други словенски језик био изборни предмет. У академској 2013/2014. години наставу српског језика пратила су 22 студента, а већ наредне академске године интересовање за похађање наставе исказало је преко 30 студената. Настава је била организована кроз шест једносеместралних стручно-апликативних курсева (у оквиру предмета Српски језик 1, 2, 3, 4, 5 и 6), а поред часова српског језика студенти су се упознавали са српском књижевношћу и елементима српске културе. Укупан фонд часова на недељном нивоу износио је 4+4, што значи да су студенти пратили 360 минута наставе предавања и вежби.

За реализацију наставе, предавачи користе исте дидактичке уџбенике и приручнике као и колеге са Универзитета Македонија. Поред наведених уџбеника и приручника, предавачи приступају самосталној изради и других дидактичких материјала, што наставни процес чини интересантнијим, занимљивијим и веома инспиративним. Поред усвајања знања о језику, студенти се кроз горенаведене уџбенике и приручнике упознају и са нашом културом и обичајима, што је од веома велике важности. Дакле, поред језичких садржаја, пожељно је да уџбеник упозна стране студенте са српском културом, традицијом и обичајима, односно друштвеном стварношћу, у складу са

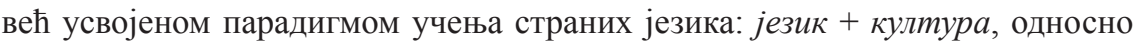
„култура посредством језика, језик посредством културе” (Раичевић 2007: 23). Ово не значи ништа друго до то да страни студенти треба да се упознају са појмовима, представама и чињеницама које се односе на нашу, страну им културу, у ширем смислу речи, током учења и усвајања језика у свим домени-

${ }^{14}$ Катедра за словенске студије основана је 2007. године актом председника Републике Грчке бр. 136/31-7-2007, а прве студенте примила је академске 2008/2009. године. Председничким указом бр 78/04-08-2016 промењени су назив катедре, као и организациона стуктура. Од академске 2016/2017. године студенти се уписују на један од укупно два студијска профила под новим именом новонастале Катедре за руски језик, филологију и словенске студије: Руски језик и књижевност, и Студије славистике. За више информација в. http://www.slavstud.uoa.gr/fileadmin/slavstud. uoa.gr/uploads/TMHMA/P.D_TMHMATOS.pdf и http://www.slavstud.uoa.gr/fileadmin/slavstud.uoa. gr/uploads/TMHMA/FEK_A_143_-_04.08.2016.pdf. 
ма говорне делатности, док целокупни наставни процес представља трансмисију стране, у нашем случају српске културе (Кончаревић 2005: 217-226).

Након прве године учења, студенти су могли да се писано и усмено изражавају на A1 нивоу, након друге године учења на A2 нивоу, док су након треће године постизали комуникативну компетенцију на Б1, односно Б2 нивоу Заједничког европског оквира за језике. Овде је реч је о високомотивисаним појединцима, који су уложили доста самосталног рада како би продубили и проширили своја знања, а самим тим и постигли праг знања у учењу српског језика као страног. Овакви студенти се могу укључити регуларно у наставу на високошколским установама у Србији и пратити наставу на српском језику

Почетак наставе српског језика и књижевности на овој катедри везује се за др Биљану Турањанин Николопулос, која је прве две године наставу изводила на волонтерској бази ${ }^{15}$. Након готово три године, у летњем семестру академске 2015/2016. године, уз помоћ пројекта Европске уније ЕСПА ${ }^{16}$, решен је проблем финансирања предавача ${ }^{17}$. Програми Националног стратегијског

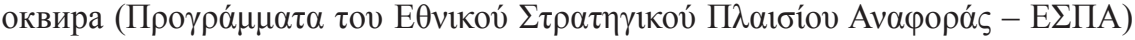
финансијски помажу едукативне пројекте на сва три нивоа образовања (основношколском, средњошколском и високошколском). Основни циљ им је повезивање тржишта рада са образовним институцијама, развијање целоживотног учења и пружање помоћи младим истраживачима и научницима.

Међутим, проблем финансирања наставног кадра битно утиче на квалитет извођења наставе, будући да се одговор Европске комисије чека и по неколико месеци. Самим тим, настава не почиње са почетком нове академске године, што битно утиче на мотивацију студената, као и на то да ли ће одабрати српски као други словенски језик. Други проблем се огледа и у самој европској регулативи, јер је програмом ЕСПА било предвиђено финансирање само два, односно четири једносеместрална предмета. То значи да су наставу у оквиру курсева Српски језик 5 и 6 предавачи држали на волонтерској бази. Од академске 2018/2019. године, Катедра је поднела захтев надлежним органима одговорним за ЕСПА програм, како би се обезбедила средства за реализацију укупно шест једносеместралних предмета: Српски језик 1, 2 и 3 (са српском књижевношћу), односно Српски језик 4, 5 и 6 (са елементима српске културе).

Након одслушане наставе, студенти су закључно са 2017/2018. годином полагали завршни семестрални испит, који је делимично урађен према моделу испита Центра за српски као страни језик (диктат, транскрипција текста са латинице на ћирилицу, провера вештине читања, провера знања о језику, писање састава на задату тему и усмена продукција).

\footnotetext{
${ }^{15}$ Посредством представништва Републике Српске у Солуну, добијена је финансијска помоћ за реализацију наставе током друге године ангажовања др Б. Турањанин.

16 За више информација в. http://www.edulll.gr/.

${ }^{17}$ Поред др Биљане Турањанин Николопулос, која наставу држи од првог дана, од летњег семестра академске 2016/2017. године ангажован је и др Полидорос Горанис, а само у том семестру наставу је држала и др Ирена Богдановић.
} 


\section{4. Институт за балканолошке студије у Солуну}

Најдужу традицију у реализацији наставе српскохрватског језика на институционализованом нивоу свакако има Школа за балканске језике при Институту за балканолошке студије у Солуну. Школа за балканске језике и руски језик при овом институту баштини традицију дужу од 55 година, а заслугом професора Јоаниса Лампсидиса настава српскохрватског језика одржава се још од давне 1965. године.

Према доступним подацима, од академске 1965/1966. године, па све до 2007. године, курс је пратило и са успехом завршило 430 ученика (Георгини/ Мустакидис/Меритас 2007: 278). Данас се настава српског језика као страног реализује у складу са начелима Заједничког европског оквира за језике, што значи да се полазници курсева припремају за усмено и писано изражавање на српском језику, развијајући како рецептивне (слушање и читање), тако и продуктивне (писање и говор) језичке активности на А1, А2, Б1, Б2, Ц1 и Ц2 нивоу. Основни циљеви наставе су постизање комуникативне компетенције на српском језику, али и развијање лингвистичке компетенције код полазника курсева. Када је реч о дидактичким материјалима и приручницима, у настави се користе уџбенички комплети Српски језик за странще Института за стране језике у Београду, Научимо падеже ауторке Весне Крајишник, али и други наставни материјали које предавачи састављају и по потреби прилагођавају нивоу знања полазника курса.

Од 2004. године, на основу споразума потписаног између Филолошког факултета Универзитета у Београду и Института за балканолошке студије, полазници курсева, али и други заинтересовани кандидати могу у Солуну проверити своје знање и стећи сертификат о познавању српског језика на једном од поменутих шест нивоа. Сматрамо да је ово добар начин да кандидати који уче наш језик учествују у оваквом виду екстерне евалуације, будући да је реч о стандардизованим тестовима који се израђују у Центру за српски као страни језик, по утврђеним мерилима и критеријумима.

У наставку наводимо број кандидата који су полагали и број кандидата који су положили испит о познавању српског језика у Институту за балканолошке студије у Солуну, у последњих девет година. Из приложене табеле може се извући закључак да је заинтересованост кандидата за стицање сертификата о познавању српског језика углавном уравнотежена, односно да приближно једнак број кандидата полаже испит сваке године пред Комисијом Центра за српски као страни језик Филолошког факултета Универзитета у Београду. 


\begin{tabular}{|c|c|c|c|c|c|c|c|c|c|c|c|c|c|c|}
\hline Го- & \multicolumn{2}{|c|}{ A1 } & \multicolumn{2}{|c|}{$\mathbf{A 2}$} & \multicolumn{2}{|c|}{$\mathbf{6 1}$} & \multicolumn{2}{|c|}{ Б2 } & \multicolumn{2}{|c|}{ Ц1 } & \multicolumn{2}{|c|}{ Ц2 } & Пола- & Поло- \\
\hline 2010. & 1 & 1 & 3 & 2 & 6 & 1 & 8 & 6 & 5 & 2 & 1 & 1 & 24 & 13 \\
\hline 2011. & l & / & 1 & / & I & / & 7 & 3 & 1 & 1 & 3 & 2 & 11 & 6 \\
\hline 2012. & \multicolumn{12}{|c|}{ располажемо само укупним подацима за све нивое } & 11 & 7 \\
\hline 2013. & 1 & 1 & 3 & 2 & 7 & 5 & 7 & 6 & 1 & 0 & I & / & 19 & 14 \\
\hline 2014. & 1 & I & 4 & 3 & 2 & 1 & 9 & 8 & 2 & 0 & 1 & / & 17 & 12 \\
\hline 2015. & I & I & 2 & 1 & 1 & 1 & 5 & 3 & 1 & 0 & 2 & 2 & 11 & 7 \\
\hline 2016. & 2 & 2 & 1 & I & 4 & 3 & 11 & 7 & I & I & 1 & 1 & 18 & 13 \\
\hline 2017. & 1 & I & 1 & 1 & 3 & 3 & 8 & 4 & 3 & 1 & 1 & 1 & 16 & 10 \\
\hline 2018. & I & I & 2 & 2 & 3 & 3 & 7 & 3 & 1 & 1 & 2 & 2 & 15 & 11 \\
\hline & & & & & & Г & & & & & & & 142 & 93 \\
\hline
\end{tabular}

Имајући у виду све до сада наведено, треба истаћи и ставове које Б. Станковић наводи, у вези са учењем и наставом српског језика као страног у иностранству (Станковић 1999: 281-284):

- Мора се водити рачуна о дидактичкој целовитости језика, књижевности и културе;

- Изучавање српског језика није само себи циљ, већ медиј помоћу ког ће странци упознати на најбољи начин српску књижевност и културу, историју, али и стање у коме се налазе наша земља и њени становници;

- Дидактичка целовитост је посебно важна када је реч о српском језику, имајући у виду чињеницу да је распострањеност српске културе, књижевности и језика шира од територије државе српског народа;

- Дидактичка целовитост језика, књижевности и културе подразумева и принцип ширег контекста, дакле развијање свести о узајамној повезаности српског језика, књижевности и културе са осталим словенским, и посебно јужнословенским језицима, књижевностима и културама.

\section{5. Мотивација за учење српског језика}

Досадашња истраживања у вези са учењем српског језика као страног показују код студената присуство како интегративне мотивације, „која делује када при учењу страног језика показујемо заинтересованост за упознавање одређене језичке групе и жељу за интеграцијом у средину чији језик учимо” (Гарднер/Ламберт 1959: 267), тако и инструменталне мотивације, „која је подређена утилитарним вредностима добијеним услед одређеног језичког 
постигнућа" (Гарднер/Ламберт 1959: 267). Стојичић и Мутавџић у својој студији анализирали су утицај различитих мотивационих фактора, али и друштвених околности које су утицале да студенти са Универзитета Македонија у Солуну уче српски језик као страни. Будући да је студијским програмом основних академских студија на Катедри за балканске, словенске и источне студије српски језик био изборни предмет, анализирани узорак није био у правом смислу репрезентативан, јер је анкетираних студената било свега двадесет. Студија је показала да се за српски језик опредељују због увиђања сличности између руског језика (који им је био обавезан предмет) и српског језика на морфосинтаксичком и лексичком нивоу, као и због постојања „тесних економских, пријатељских и филхеленских веза између Срба и Грка, показујући тиме да су упућени у наше савремене друштвене и политичке токове” (Стојичић/Мутавџић 2011: 275). С тим у вези, појам језичког тржишта (Калве 2000: 154) нам указује на непостојање неутралности процеса ширења језика у свету. Као битна социолошка категорија, указује нам у којој мери је један језик пожељан и привлачан за учење на међународном нивоу. То значи „да се један одређени систем сачињен од елемената друштво-култура-језик шири само ако другим друштвеним субјектима успе да понуди нешто што је у стању да задобије пажњу и вредност” (Вучо/Недељковић/Митић 2007: 501).

Још једно истраживање о мотивационим факторима који утичу на учење српског језика као страног приказано је у студији Биљане Николић. Ауторка закључује да на учење српског језика као страног „утичу спољашњи фактори, пре свега, избор факултета/школе, професионална оријентација и будући позив" (Николић 2014: 56).

Захваљујући Споразуму о научној сарадњи бр. 326/1 од 1. априла 1996. године, који је потписан између Универзитета у Београду и Аристотеловог универзитета у Солуну, пронађен је и правни основ за продубљивање сарадње између Катедре за неохеленске студије Филолошког факултета Универзитета у Београду и Центра за српски као страни језик са једне, односно Аристотеловог универзитета у Солуну, са друге стране. Потписивањем Анекca 1 Споразума о сарадњи бр. 68-4279/2-11 од 14. фебруара 2011. године, предвиђено је да студенти са Аристотеловог универзитета у Солуну прате наставу српског језика као страног у оквиру Летњег програма Центра за српски као страни језик. У наставку наводимо укупан број студената са Аристотеловог универзитета у Солуну, који су добили стипендију за похађање наставе српског језика као страног током Летњег курса, од 2012. године до данас. Из приложених података јасно је да Филолошки факултет чини огромне напоре како би што више студената из Грчке, добило прилику да уче, односно усавршавају знање српског језика у Београду. 


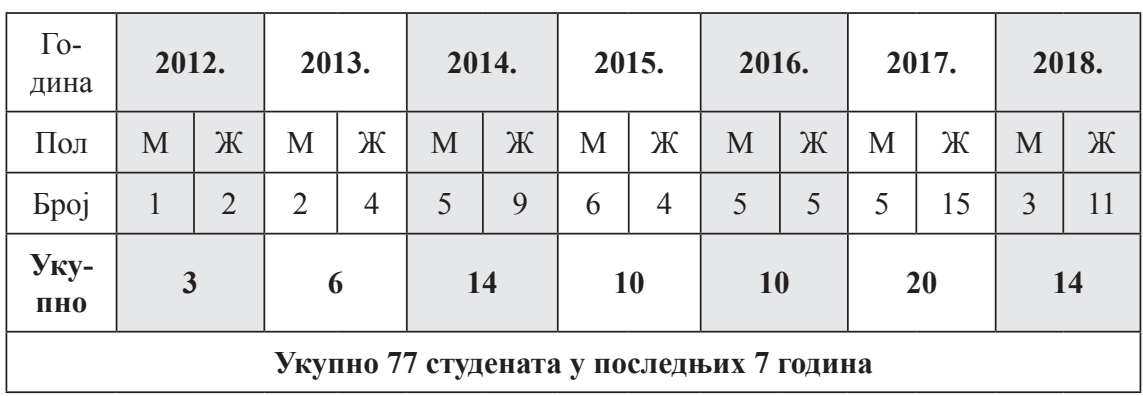

Како су студенти уз апликацију за учешће у овом програму достављали и мотивациона писма, у прилици смо били да анализирамо разлоге због којих су се одлучили за похађање наставе српског језика, током тронедељног Летњег курса. Кандидати су у виду краћег есеја наводили разлоге због којих желе да науче српски језик или разлоге због којих су до сада учили наш језик, а које приказујемо у табели ниже. Анализирана су сва мотивациона писма, а добијени одговори су класификовани према процентуалној вредности, почевши од највећег броја истих фактора који су утицали на одабир Летњег програма ${ }^{18}$ српског језика као страног на Филолошком факултету у Београду.

\begin{tabular}{|l|c|}
\hline \multicolumn{1}{|c|}{ Разлози због којих студенти из Грчке желе } & \multicolumn{1}{|c|}{ да науче/ усаврше српски језик } \\
\hline $\begin{array}{l}\text { За летњи курс српског језика као страног пријављујем се због блискости } \\
\text { Срба и Грка, односно историјских, верских и културних веза које наша } \\
\text { два братска народа вековима негују. }\end{array}$ & 24 \\
\hline $\begin{array}{l}\text { Будући да у Грчкој летује велики број грађана Србије, познавање српског } \\
\text { језика омогућило би ми лакше и брже проналажење посла како у струци, } \\
\text { тако и ван ње. }\end{array}$ & 21 \\
\hline $\begin{array}{l}\text { Познавање српског језика од суштинске је важности за моје даље школо- } \\
\text { вањеу , јер ми омогућава консултовање литературе, историјских и књи- } \\
\text { жевних извора написаних на српском језику. }\end{array}$ & 13 \\
\hline $\begin{array}{l}\text { Имам пријатеље из Србије, а упознали смо се током студентских размена } \\
\text { у Грчкој/ Србији/ некој другој земљи Европе. }\end{array}$ & 10 \\
\hline $\begin{array}{l}\text { Будући да познајем друштвене и политичке токове, схватам да нас ви } \\
\text { Срби као народ поштујете, те часови српског језика представљају одлич- } \\
\text { ну прилику да Србију упознам још боље, као и да са другим студентима } \\
\text { размењујем знања и сазнања о различитим друштвеним темама. }\end{array}$ & 7 \\
\hline
\end{tabular}

${ }^{18}$ Тронедељни курс траје током јула месеца сваке године, а настава се реализује на три нивоа: почетном, средњем и вишем. Поред часова српског језика, наставници и сарадници Филолошког факултета студентима странцима организују посете музејима и другим релевантним институцијама од културног значаја у Београду.

${ }^{19}$ Овај разлог су наводили, готово без изузетка, студенти византијске филологије на Филозофском факултету у Солуну. 
Познавање словенских језика омогућава ми лакше проналажење посла у инословенској средини, јер су миграторна кретања Грка данас већа него што су била икада у 21. веку.

Уколико научим добро српски језик, без проблема могу да се споразумевам са народима који живе у околним земљама (Србија, Босна, Хрватска, Црна Гора), јер сви говорите исти језик.

Будући да сам српског порекла, усавршавање језика би попунило ону празнину, која постоји када је реч о лексици која припада вишем језичком стилу, јер код куће не говорим увек српски језик са оба родитеља, а тешко ми је да разумем рођаке из Србије.

Као град који спаја балканско и европско, старо и модерно у историјском смислу, Београд представља идеалну дестинацију за тронедељни боравак.

Будући да сте земља спорта и спортиста, желео бих на наставим студије
на ДИФ-у, а то је немогуће уколико не говорим српски.
на ДИФ-у, а то је немогуће уколико не говорим српски.

Познавање српског језика омогућава ми читање класика српске књижевности у оригиналу.

Познавање српског језика омогућило би ми учествовање у даљим археолошким истраживањима у Виминацијуму.

Српски је језик мојих предака, а стицајем околности га не говорим.

(1)

\section{6. Закључак}

Имајући у виду све до сада речено, Република Србија и њене надлежне институције морају уложити више напора и финансијских средстава како би се настава српског језика реализовала на што више универзитета у свету. Странци који уче наш језик свејеврсни су језички и културни амбасадори наше земље у иностранству и могу допринети формирању позитивнијег мишљења о Србији и њеним грађанима, које је промењено након почетка рата деведесетих година и увођења санкција. Мишљења смо да Србија на овакав начин може утицати и на слику коју светски медији преносе о нама, јер жива реч подједнако утиче на формирање ставова, промену мишљења и отклањање уврежених стереотипа.

Анализа анкете показала је колику важност студенти са Аристотеловог универзитета у Солуну придају значају јачања и неговања добрих односа између наша два народа, познајући у великој мери историјске, верске и културне чиниоце који нас повезују. Познавање српског језика је важно и због остваривања професионалних циљева у смислу радног ангажовања, било кроз сезонске послове у туризму, али и могућности за заснивање сталног 
радног односа у компанијама које послују са Србијом и регионом. Најзад, студенти српског порекла имају жељу за усавршавањем језика и што бољим упознавањем културе и традиције земље из које воде порекло.

Србији је потребнија свестранија научна, просветна и културна сарадња са свим народима света, посебно имајући у виду европску политику, јер успешна сарадња на овим пољима подстиче стварање позитивних екстралингвистичких фактора који обезбеђују бољу перспективу учења свих словенских језика како у инословенској средини (Раичевић 2007: 19), тако и када је реч о сарадњи словенских народа са другим народима света.

\section{ЛИТЕРАТУРА}

Вучо/Недељковић/Митић 2007: Julijana Vučo, Milica Nedeljković, Ivana Mitić, Italija s ove strane Jadrana. Motivacioni stavovi i kulturni stereotipi studenata italijanistike, $u$ : J. Vučo (red.), Savremene tendencije u nastavi jezika i književnosti, Beograd: Filološki fakultet, 499-507.

Гарднер/Ламберт 1959: Robert Gardner, Wallace Lambert, Motivational Variables in Second-Language Acquisition. Canadian Journal of Psychology, 13 (4), 266-272. 〈https://files.eric.ed.gov/fulltext/ED031968.pdf〉.23.09.2018.

Георгини/Мустакидис/Меритас 2007: Ксенија Георгини, Сотириос Мустакидис, Илиас Меритас, Српски као страни језик на Балканолошком институту И.М.Х.А у Солуну, $y$ : В. Крајишник (ред.), Српски као страни језик у теорији и пракси, Београд: Филолошки факултет, 277-285.

Калве 2000: Louis-Jean Calvet, Le marché aux languages. Paris: Plon.

Кончаревић 2005: Ксенија Кончаревић, Презентација српске културе у уџбеницима српског језика као страног: теоријски оквир и конструкцијска решења, Научни састанак слависта у Вукове дане, 34/1, 217-228.

Николић 2014: Biljana Nikolić, Motivacija u učenju L2 - teorijski okvir i nekoliko zapažanja o motivaciji za učenje srpskog kao L2, Primenjena lingvistika $14,51-58$.

Раичевић 2007: Вучина Раичевић, Општа методика наставе словенских језика у инословенској средини, Београд: Завод за уџбенике.

Станковић 1999: Богољуб Станковић, Актуелни проблеми изучавања српског језика у иностранству, Славистика III, 271-284.

Стојичић 2016: Војкан Стојичић, Рецептивне језичке активности у универзитетској настави страног језика - релаиије између модерног грчког и српског језика, необјављена докторска дисертација, 〈file:///C:/Users/USER/Downloads/DOKTORSKA\%20DISERTACIJA_ VOJKAN\%20STOJICIC\%20(8).pdf 〉.23.09.2018.

Стојичић/Мутавџић 2011: Војкан Стојичић, Предраг Мутавџић, Мотивација грчких студената за учење савременог српског као страног језика, y: В. Крајишник (ред.), Српски као страни језик у теорији и пракси II, Београд: Филолошки факултет, 267-280. 


\section{ПРИРУЧНИЦИ}

Алановић и др. 2007: Milivoj Alanović, Isidora Bjelaković, Nataša Bugarski, Jasmina Dražić, Marina Kurešević, Jelena Vojnović, Научимо српски 2: Let's Learn Serbian 2, Нови Сад: Филозофски факултет.

Бјелаковић/Војновић ${ }^{32010}$ : Исидора Бјелаковић, Јелена Војновић, Научимо српски 1: Let's Learn Serbian 1, Нови Сад: Филозофски факултет.

Живанић/Здравковић/Путник 2012: Љубица Живанић, Смиља Здравковић, Бранимир Путник, Српски језик за страние. Више од речи: средњи течај, Београд: Институт за стране језике.

Крајишник 1998: Весна Крајишник, Научимо падеже, Београд: Фото Футура.

Милићевић Добромиров/Новковић Аџаип 42013: Наташа Милићевић Добромиров, Биљана Новковић Аџаип, Учимо српски 1, Нови Сад: Азбукум.

Селимовић Момчиловић/Живанић '2012: Маша Селимовић-Момчиловић, Љубица Живанић, Српски за странце. Реч по реч: почетни течај, Београд: Институт за стране језике.

Vojkan B. Stojičić

SERBIAN AS A FOREIGN LANGUAGE IN GREECE - CHALLENGES AND PERSPECTIVES

Summary

This paper introduces the current position of the Serbian language as a foreign language in the Republic of Greece at the university level. We analyzed the status of Serbian language at the Faculty of Philosophy at the National and Kapodistrian University of Athens, at the University of Macedonia in Thessaloniki, but also at the Institute for Balkan Studies in Thessaloniki. Finally, we present the data related to the motivation for learning Serbian as a foreign language.

Key words: Serbian as foreign language, teaching, Republic of Greece, motivation, learning. 